\title{
Application of Economic Value Added under the Conditions of Globalization: Study of Real Estate Industry
}

\author{
Ivana Podhorska ${ }^{1, *}$ \\ ${ }^{1}$ University of Zilina, Faculty of Operation and Economics of Transport and Communications, \\ Univerzitna 1, 01026 Zilina, Slovakia
}

\begin{abstract}
Research background: The success and stability of any company depends mainly on its financial health. This research is focused on the application of economic value added as a methods for analysis of financial health of company. The EVA indicator characterizes the company's ability, which is reduced by the price of equity. In other words, the capital invested in the company has a benefit that exceeds the cost of that capital. The goal of each owner is to achieve the maximum possible appreciation of this invested capital and thus ensure the appreciation of the company's assets. Purpose of the article: The main aim of the paper is to assess the financial health of companies in the real estate industry by economic added value under the conditions of globalization.

Methods: For research was used the data of Slovak enterprises from real estate industry, obtained from annual financial reports covering the year 2019. Based on these data economic value added were calculated. Especially, EVA equity methods was used. Cost of equity were quantified by capital assets pricing model. Subsequently, the results obtained were examined by descriptive statistics.

Findings \& Value added: The results of paper bring comprehensive analysis of financial health of Slovak companies from real estate industry by economic value added. Paper identified the value of economic value added in all companies from this industry, quantified both, the largest and the smallest values of economic value added in data. Subsequently, study applied descriptive analysis of results.
\end{abstract}

Keywords: economic value added; real estate; globalization

JEL Classification: $G 3 ;$; 32

\footnotetext{
* Corresponding author: ivana.podhorska@,fpedas.uniza.sk
} 


\section{Introduction}

Following the outbreak of the pandemic in 2020, many real estate market experts believed that it would significantly mark its devellopemnt and that the prices rising so far each year would see a huge drop. (Kaplan and Stromberg, 2003) They feared that people lose interest in buying and renting apartments and houses due to the looming crisis and would postpone their plans until the pandemic was over. (Koijen et al., 2016) However, the impact of the pandemic was reflected in the activities of real estate agencies, which had to close their operations and personal inspections of houses and flats were replaced by digital ones. The reason why real estate prices are so high is the fact that demand far exceeds supply. (Berzakova et al., 2015) The following figure no. 1 shows the development of real estate prices over the last 15 years.

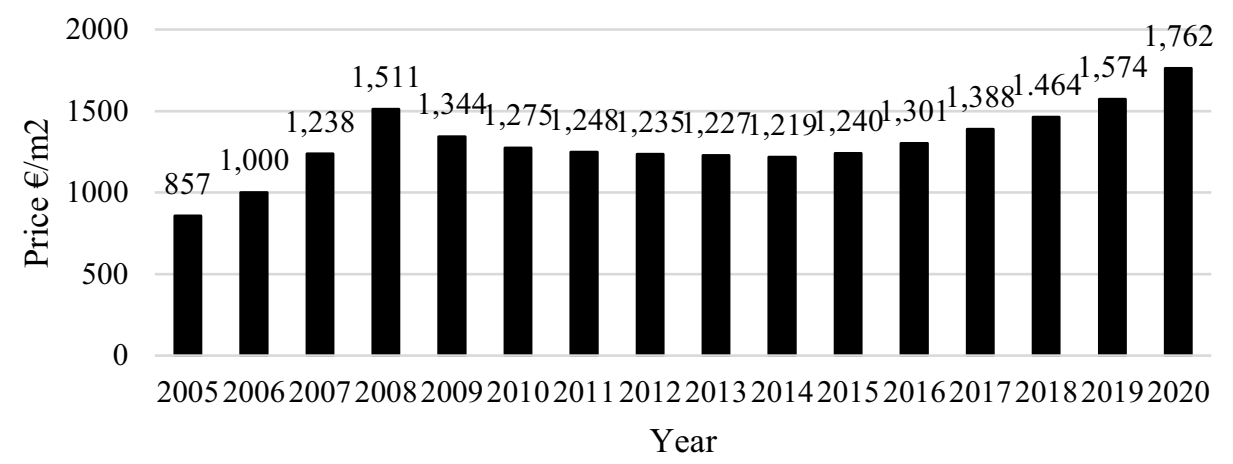

Figure 1. Development of real estate prices in the Slovak Republic 2005-2020

Source: own processing according to NBS

The price of real estate in 2020 increased by $11.9 \%$ compared to the previous year. The Bratislava region contributed the most to this growth, but prices also rose in the Prešov and Banská Bystrica regions. In other regions, we recorded stagnation or only a slight decrease over the past year. (Slavicek, 2015; Brahm et al., 2021) If we compare real estate prices, e.g. in the second quarter of 2019 and 2020, prices in 2020 are 16\% higher. The paradox is that these high real estate prices have been accompanied by the most significant economic downturn to date. The real estate market maintained its growth mainly due to the fact that it was not a structural complication, but only external influences. Short releases have shown that the real estate market has the ability to return to pre-pandemic conditions very quickly. (Dorobantu and Odzjemkowska, 2017; Krishnan, 2021) With the exception of the initial period of the pandemic, we did not notice any major damage to this market. Experts assume only a very small probability of lowering property prices in the coming period, which means that the situation in the real estate market will depend only on property owners and their willingness to sell their houses or apartments. (Lee and Ryu, 2017; Wagner, 2016; Tschirhart, 2007)

In the case of price development in individual regions, the situation is not the same. While in some the average price of real estate is rising, in others it is relatively stable and this fact changes in individual regions every year. (Breza and Kinnan, 2021; Reck et al., 2021) However, in general, from a longer time point of view, we can say that in each region prices are rising faster or slower, as demonstrated by the following figure no. 2 , which shows the development of real estate prices in individual regions in 2005-2020. 


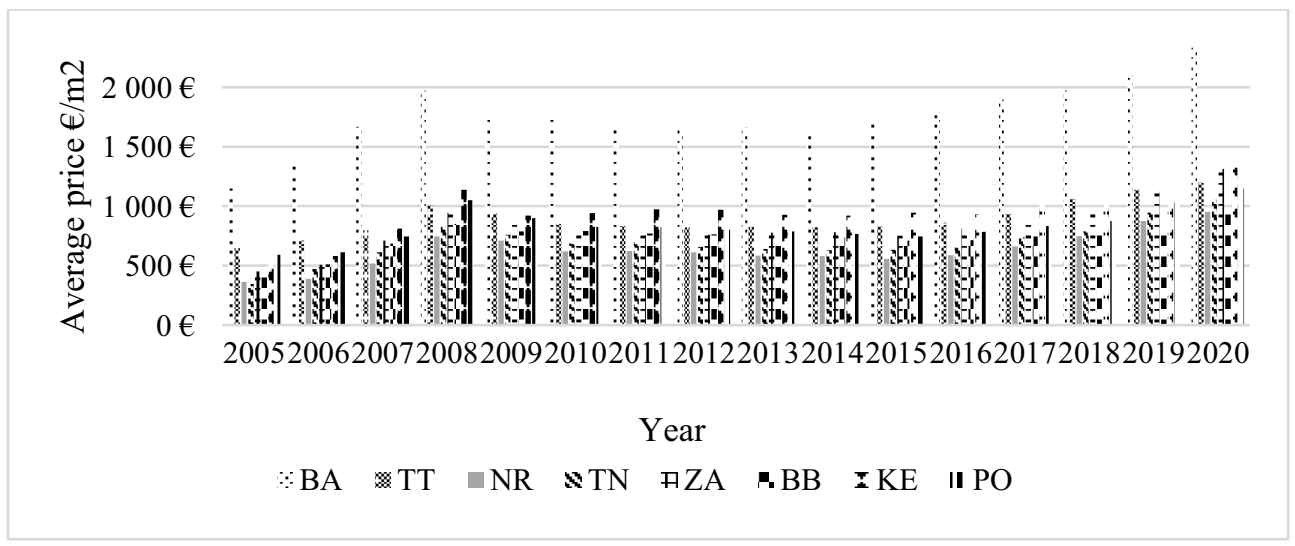

Figure 2. Real estate prices by region 2005-2020

Source: own processing according to NBS

\section{Methodology and data}

\subsection{Economic Value Added}

If we want to compare and evaluate the performance of companies in a way that makes companies comparable to each other, there are countless ways and methods. However, we often encounter obstacles where it is necessary to adapt various aspects to certain requirements and also by the calculation procedure in exactly the way that we achieve that the analyzed companies will be comparable. We chose the EVA indicator because this indicator is just such an indicator that can evaluate and analyze companies in a way that makes them comparable. (Reck et al., 2021; Rosch, 2021) We can consider it as an economic indicator of the financial health of companies.Marshall first mentioned Economic Value Added („EVA“) in 1880, and today and in recent years it is best known for the Stern Stewart \& Company. The EVA indicator characterizes the company's ability, which is reduced by the price of equity. In other words, the capital invested in the company has a benefit that exceeds the cost of that capital. It is a measure of the efficiency of the use of invested capital. (Siekelova et al., 2019; Valaskova et al., 2021) The goal of each owner is to achieve the maximum possible appreciation of this invested capital and thus ensure the appreciation of the company's assets. (Belitski et al., 2021; Kraatz et al., 2020) This indicator is often referred to as economic profit, in which we speak of the difference between the company's revenues and its economic costs. Among other things, EVA emphasizes the operational efficiency of the company. (Rowland et al., 2020; Clark et al., 2020) It talks about how the funds that have been put into the business are valued after their price is paid. EVA serves a variety of users, as well as management, creditors and business owners. For the largest companies, its value should be positive and should have an increasing trend over the years. In Slovakia, awareness of this indicator is slowly but surely rising and its use is growing. After stabilizing the procedure for its calculation, we will be able to compare Slovak and international companies. (Belas et al., 2018a; Belas et al., 2018b)

We distinguish 2 basic methods of calculation - EVA entities and EVA equity. (Coatney and Poliak, 2020) In this work we will use the second mentioned. EVA equity is a calculation of economic value added based on the cost of equity. Its quantification is as follows:

$$
E V A=E *\left(\mathrm{ROE}-r_{e}\right)
$$


Where:

$\begin{array}{ll}E & \text { equity } \\ R O E & \text { return of equity } \\ r_{e} & \text { cost of equity }\end{array}$

\subsection{Data}

Currently, most businesses are marked and affected by a pandemic. Real estate agencies are no exception. Like other companies, they had to adapt their activities to the current situation. Real estate agents work from home, communicate via e-mail or telephone, which is not a big limitation compared to the previous situation, but the limitation occurs when inspecting real estate with clients, which are currently very limited. Nevertheless, real estate agencies continue to operate. The following figure shows the percentage of real estate agencies in individual regions of the Slovak Republic.

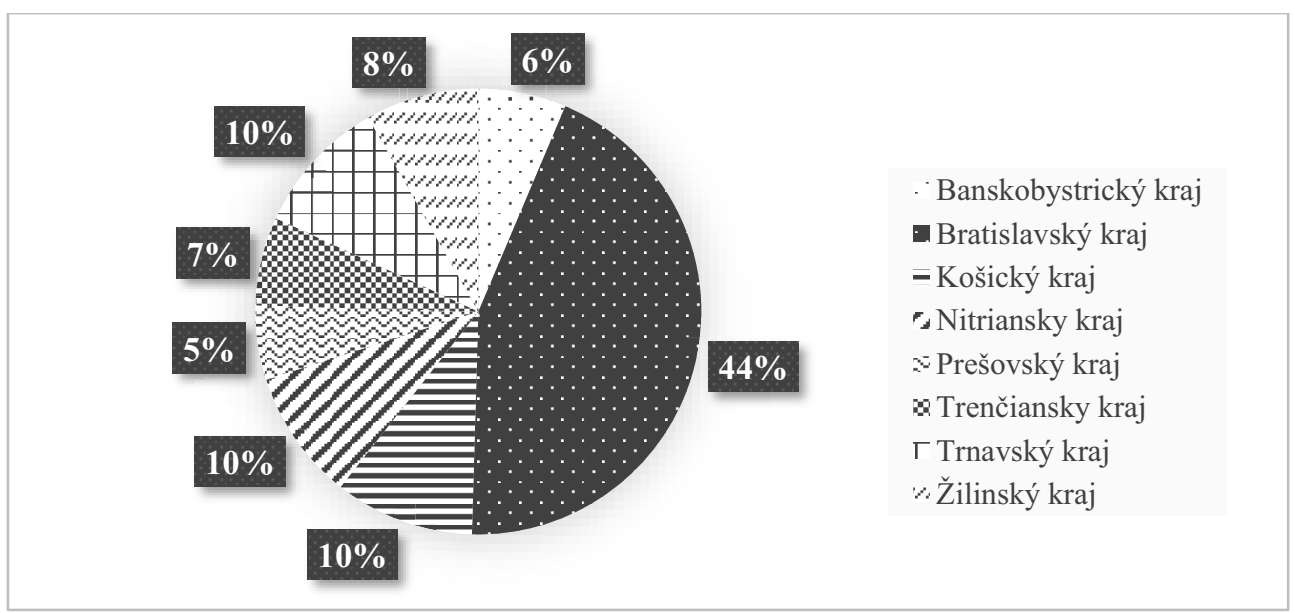

Figure 3. Percentage representation of real estate agencies in individual regions of the Slovak Republic

Source: own processing according to nehnutelnosti.sk

Most real estate agencies almost 50\% are located in the Bratislava region. This is justified, as in this region there is also the greatest demand for real estate. The supply of real estate here is also significantly higher than in other regions. In these, the representation of real estate agencies is about the same, in the range of 5-10\%.

We apply the analysis to a sample of 132 real estate agencies, which we filtered from the European Amadeus database for 2020 on the basis of SK NACE. We will then select the companies that achieve the best and worst values of this indicator and we will continue to work with them and analyze them. The composition of the evaluated enterprises by region is as follows:

- Bratislava region: 61 companies

- Trnavava region: 17 companies

- Trenčín region: 7 companies

- Nitra region: 7 companies

- Žilina region: 8 companies

- Banská Bystrica region: 8 companies

- Prešov region: 5 companies

- Košice region: 19 companies 


\section{Results}

In the following tables 1 , we will list the 10 real estate agencies that showed the worst and best values of the EVA indicator in 2020 .

Table 1. Real estate agencies with the worst and the best values of the EVA indicator in 2020

\begin{tabular}{|c|c|c|c|c|}
\hline No. & Region & EVA (worst) & Region & EVA (best) \\
\hline 1 & Bratislava & $-1,964,251.50 €$ & Žilina & $10,481.10 €$ \\
\hline 2 & Banská Bystrica & $-103,560.24 €$ & Bratislava & $13,455.75 €$ \\
\hline 3 & Bratislava & $-64,994.84 €$ & Bratislava & $16,510.20 €$ \\
\hline 4 & Žilina & $-38,762.78 €$ & Košice & $21,402.41 €$ \\
\hline 5 & Bratislava & $-29,730.85 €$ & Bratislava & $34,404.03 €$ \\
\hline 6 & Bratislava & $-26,799.37 €$ & Bratislava & $39,273.89 €$ \\
\hline 7 & Bratislava & $-22,400.77 €$ & Košice & $58,816.47 €$ \\
\hline 8 & Bratislava & $-20,241.93 €$ & Trnava & $114,160.04 €$ \\
\hline 9 & Prešov & $-16,602.84 €$ & Košice & $244,458.38 €$ \\
\hline 10 & Trnava & $-14,432.57 €$ & Košice & $314,830.13 €$ \\
\hline
\end{tabular}

Source: own calculation

We can comprehensively say that in the monitored industry, in a selected sample of companies, we achieved different values of this indicator. From very satisfactory results to unfavorable to worrying ones, from financially sound and prosperous companies to those that are not prosperous, they are heading more for failure. For 50 companies, we record a negative value of the EVA indicator, which indicates that the value of the capital that the owners invested in the business decreased. For 3 companies, we could not calculate this indicator, respectively. turned out to be 0 , as these companies reported zero net profit. The average value of EVA calculated from all 132 companies is $-11,103.92 €$, this result is significantly affected by the value of the worst result, which differs significantly from other values. If we do not include this extreme value in the average, then the average added economic value of companies in the surveyed sector for 2020 is $3,920.29 €$. Based on this average value, we can state that companies in the monitored sector increase their economic added value, ie companies create value for their owners.

The lowest calculated value is $-1,964,251.50 €$ This value, as mentioned, is rapidly different from all calculated values, we even see a multiple difference compared to the second worst result. While the second worst result is in the thousands of $€$, the worst result is in the millions of $€$. We can state that these companies are losing current but also future opportunities and will probably not succeed in the future, as the economic value of these companies is declining. If we abstract from the company in Table 1, in which we did not find the number of employees, then paradoxically, the company with the largest number of employees, on the basis of which one would expect the company to prosper and prosper has the lowest economic added value. We can also see from the table that up to 6 out of 10 companies that achieved the worst values of the EVA indicator are located in the Bratislava region, this result is significantly influenced by the fact that in our sample there are almost half (61/132) companies from this region.

Enterprises with an EVA indicator of more than 0 can be considered as financially sound enterprises that create value for their owners. The analyzed file also includes a company whose value of the EVA indicator was $0.07 €$, which can be considered a company whose 
value invested by the owners in the company returns almost without appreciation. The best value of the EVA indicator for 2020 was achieved by a company from the Košice Region, its economic value for the mentioned year is $314,830.13 €$. The second best company also comes from the Košice region and its economic value is $244,458.38 €$. In this table, there are no companies from the Banská Bystrica, Prešov, Nitra or Trenčín regions at all. As far as the Bratislava region is concerned, despite the large number of enterprises that are in the monitored sample, it does not have such a significant representation in this table, it occurs in it as often as the Košice region. Based on the number of employees in individual companies, we cannot compare them exactly, as we do not record their real number for more than half of them.

We also compared the EVA indicator of individual companies operating on the real estate market in all regions of Slovakia, which we can observe in the following table. We divided the companies into groups according to the region in which they operate and carry out their activities. Subsequently, we calculated the average values of the EVA indicator for individual companies operating in the same region.

Table 2. Average value of the EVA indicator in the regions of the Slovak Republic in 2020

\begin{tabular}{|c|c|}
\hline Region & Average EVA \\
\hline Bratislava & $-17,219.51 €$ \\
\hline Banská Bystrica & $-3,092.83 €$ \\
\hline Prešov & $-2,701.52 €$ \\
\hline Žilina & $-1,505.19 €$ \\
\hline Nitra & $-628.21 €$ \\
\hline Trenčín & $-284.83 €$ \\
\hline Trnava & $2,278.69 €$ \\
\hline Košice & $10,075.13 €$ \\
\hline
\end{tabular}

Source: own calculation

Regarding the individual regions of Slovakia, we see that companies in our sector show rather unfavorable average values of the EVA indicator. We recorded the worst result in our largest region, the Bratislava region, again, this result is influenced by the worst value, which we can call extreme. If we do not include this value in the average, the EVA indicator for companies in the Bratislava region represents the value of $-952.53 €$. And so the worst region in this case would be the Banská Bystrica region. On the contrary, the best result is recorded in the second largest region, Košice, where the value of the EVA indicator is 10,075.13€. Real estate agencies in this region create value for their owners. We still record positive values of the indicator in the Trnava region. From the calculated data, we can judge that companies in the real estate sector in 2020 were more successful in eastern Slovakia.

\section{Discussion and conclusion}

Based on the quantification of the EVA indicator and the performance of individual analyzes, we were convinced that the financial health of companies cannot be assessed by means of only one indicator or one analysis. Such a procedure would be very inaccurate, even misleading. The financial health of companies needs to be analyzed and evaluated from several angles and perspectives. We have been convinced of this fact several times, the company in which we found that its added economic value is the highest among all the 
examined companies showed one of the worst results in the analysis of profitability. On the other hand, the company whose economic value added was slightly above the average value was ranked among the companies with the best results in the performed analyzes.

The first fact that we would like to draw attention to is the indebtedness of companies in the sector under review. Businesses show high indebtedness. We are aware that its amount depends on specific management decisions and company strategies, but on average, for the best companies within the EVA indicator, the total indebtedness of these companies in 2016 is more than $80 \%$ (median is even up to $96.8 \%$ ). The main aim of the paper is to assess the financial health of companies in the real estate industry by economic added value under the conditions of globalization.

\section{References}

1. Belas, J., Gavurova, B., \& Toth, P. (2018a). Impact of selected characteristics of SMEs on the capital structure. Journal of Business Economics and Management, 19(4), 592608.

2. Belas, J., Smrcka, L., Gavurova, B., \& Dvorsky, J. (2018b). The impact of social and economic factors in the credit risk management of SME. Technological and Economic Development of Economy, 24(3), 1215-1230.

3. Belitski, M., Guenther, C., \& Thurik, R. (2021). Economic effect of the COVID-19 pandemic on entrepreneurship and small businesses. Small Business Economics, early access.

4. Berzakova, V., Salaga, J., \& Majercak, P. (2015). Financial health of the company. Proceedings of the 5th International Conference on Applied Social Science (ICASS 2015), 82-+

5. Brahm, F., Parmigiani, A, \& Tarzijan, J. (2021). Can firms be both board and deep? Exploring interdependencies between horizontal and vertical firm scope. Journal of Management, 47(5), 1219-1254.

6. Breza, E., \& Kinnan, C. (2021). Measuring the equilibrium impacts of credit: Evidence from the Indian microfinance crisis. Quarterly Journal of Economics, 136(3), 14471497.

7. Clark, A., Zhuravleva, N. A., Siekelova, A, \& Frajtova Michalikova, K. (2020). Industrial artificial intelligence, business process optimization, and big data-driven decision-making processes in cyber-physical system-based smart factories. Journal of Self-Governance and Management Economics, 8(2), 28-34.

8. Coatney, K., \& Poliak, M. (2020). Cognitive decision-making algorithms, internet of things smart devices, and sustainable organizational performance in industry 4.0-based manufacturing systems. Journal of Self-Governance and Management Economics 8(4), 9-18.

9. Dorobantu, S., \& Odzjemkowska, K. (2017). Valuing stakeholder governance: Property rights, community, mobilization, and firm value. Strategic Management Journal, 38(13), 2682-2703.

10. Kaplan, S. N., \& Stromberg, P. (2003). FInancial contracting theory meets the real world: An empirical analysis of venture capital contracts. Review of Economic Studies, 70(2), 281-315.

11. Koijen, R. S. J., Philipson, T. J., \& Uhlig, H. (2016). Financial health economics. Econometrica, 84(1), 195-242. 
12. Kraatz, M. S., Flores, R., \& Chandler, D. (2020). The value of values for institutional analysis. Academy of Management Annals, 14(2), 474-512.

13. Krishnan, H. A. (2021). Mindfulness as a strategy for sustainable competitive advantage. Business Horizons, 64(5), 697-709.

14. Lee, J., \& Ryu, D. (2019). How does FX liquidity affect the relationship between foreign ownership and stock liquidity? Emerging Markets Review, 39, 101-119.

15. Reck, F., Fliaster, A., \& Kolloch, M. (2021). How to build a network that facilitates firm-level innovation: An integration of structural and managerial perspectives. Journal of Management Studies, early access.

16. Rosch, D. (2021). The impact of arbitrage on market liquidity. Journal of Financial Economics, 142(1), 195-213.

17. Rowland, Z., Krulicky, T., \& Oliinyk, O. (2020). Capital cost quantification model in business activity planning: the evidence of the middle Europe countries. Ekonomickomanazerske spektrum, 14(1), 30-42.

18. Siekelova, A., Kovacova, M., Adamko, P., \& Stehel, V. (2019). Profit management as an instrument for SMEs developing: The case for Slovakia. Marketing and Management of Innovations, 3, 285-296.

19. Slavicek, O. (2015). The predictive model of financial health for companies in the construction sector. Proceedings of the 10th International Scientific Conference, Financial Management of Firms and Financial Institutions, 1166-+

20. Tschirhart, M. (2007). Players in the public policy process: Nonprofits as social capital and agents. Public Management Review, 9(1), 164-165.

21. Valaskova, K., Adamko, P., Frajtova-Michalikova, K., \& Macek, J. (2021). Quo Vadis earnings management? Analysis of manipulation determinants in Central European environment. Oeconomia Copernicana, 12(3).

22. Wagner, U. J. (2016). Estimating strategic models of international treaty formation. Review of Economic Studies, 83(4), 1741-1778.

23. Vývoj cien nehnutel'ností v rokoch 2018 a 2019 [online] 2019. Avaliable at: $<$ https://edenreal.sk/2019/10/01/vyvoj-cien-nehnutelnosti-v-rokoch-2018-a-2019/>

24. Vývoj slovenského realitného trhu z regionálneho pohl'adu [online] 2018. Available at : $<$ http://www.nbs.sk/_img/Documents/_PUBLIK_NBS_FSR/Biatec/Rok2018/022018/Biatec_18_2_05Car.pdf> 